\title{
MODERATING EFFECTS OF TECHNOLOGY READINESS ON ATTITUDES AND RESPONSES TO MOBILE CHECK-IN AT SOUTH AFRICAN AIRPORTS
}

\author{
Gregory John Lee ${ }^{a}$, Sumeshin Naidoo ${ }^{b}$ \\ a University of the Witwatersrand, Johannesburg, South Africa \\ b Former MBA student at Wits Business School, Johannesburg, South Africa \\ Corresponding email: gregory.lee@wits.ac.za
}

\begin{abstract}
Self-service check in has become a norm for passengers in the worldwide airline industry. However, this broader methodology of check-in is dominated by the use of the internet over other self-service check-in channels such as kiosks and mobile. Check in options such as mobile do, however, remain important to airlines for a variety of reasons. This paper therefore examines some factors involved in the choice to enact mobile check-in within a sample of over 700 South African airline passengers. Notably, we examine whether technological readiness of passengers moderates the relationships between attitude towards mobile check-in and positive response to the experience, as well as adoption of mobile check-in and positive response. These moderation relationships are supported for technological optimism specifically, which when higher is associated with stronger positive relationships between attitudes and responses and adoption and responses. Implications and recommendations are discussed.
\end{abstract}

Keywords: Airports, Check-in, Mobile, Self-service, Technological Readiness, South Africa.

\section{Introduction}

The purpose of this research is to assess the effects of technology readiness (TR) on relationships between passengers' attitudes toward, adoption of, and responses to mobile phone check-in technologies in South Africa.

Global trends have strongly leaned toward the use of self-service check-in technologies at major airports and for airlines world-wide. According to the 2016 Passenger IT Trends Survey (Air Transport World \& SITA, 2016), 57\% of global passengers made use of self-service check-in, of whom 91\% said that they would keep using self-service. However, the modes of self-service are not equally distributed, with internet accounting for $31 \%$ of all check-ins; kiosks $14 \%$, and mobile lagging at $12 \%$.

This research; therefore, focuses on mobile as the least-used self-service technology check, and seeks to explore a specific element which may facilitate its adoption, namely technological readiness.

The specific context of this study is South African airports, as discussed next.

\section{Context of the Study}

South Africa is the most developed country on the African continent in many respects, including in airport infrastructure. Airports Company South Africa (ACSA) owns and operates South Africa's nine principal airports, comprising of three major international gateways, at Johannesburg, Durban and Cape Town, as well as six domestic airports, and has garnered commissions to operate other airports internationally (Airports Company South Africa, 2017). 
As with most developing economies, South Africa has seen expansive growth in international carriers as well as low-cost airlines competing aggressively for passengers, market share and cost savings. ACSA and these airlines have followed international trends in partnering around and extensively implementing self-service technologies for check in, which are believed to facilitate customer flexibility and satisfaction, as well as airport and airline cost savings.

Mobile technologies are important options in the South African context. Whereas internet penetration is relatively low in South Africa, and internet usage remains hampered by poor bandwidth, mobile penetration has been remarkable across the continent (Pew Research Center, 2015), with far more South Africans having access to cellphones than landline technologies and with smartphone usage rising fast. This suggests that mobile options may increase in importance as a self-service methodology in the airline sector, as well as many other similar sectors.

The following section discusses the model employed in this paper.

\section{Model}

The introduction of self-service technologies may not automatically lead to their usage, as has been seen with the relatively low worldwide adoption of mobile as a self-service check-in option. A need exists to understand factors which might influence customer choices and responses since development and maintenance of mobile technologies is by no means cost-free.

This paper focusses on an individual's technological readiness (TR), defined as "propensity to embrace and use new technologies for accomplishing goals in home life and at work" xviii. This construct was developed by Parasaruman (2000) due to evidence of increasing customer frustration in dealing with technology-based systems, and is therefore useful in trying to understand relatively low take-up of mobile check-in.

Research has found that TR can be an important element in consumer perceptions of and behaviors towards self-service technologies (Lin \& Hsieh, 2005 \& 2006; Zeithaml et al., 2002; Tsikriktsis, 2004; Liljander, Gillberg, Gummerus \& van Riel, 2006; Taylor, S. A., Celuch \& Goodwin, 2002; Lin \& Chang, 2011). TR may act essentially as a facilitating factor if the individual is generally accepting of new technology or as an inhibiting factor if the individual finds new technology stressful or in some other way, perceives it negatively (Dabholkar, 1996 \& 2000; Dabholkar \& Bagozzi, 2002; Curran, Meuter \& Surprenant, 2003; Mick \& Fournier, 1998; Lu, Chou \& Ling, 2009). Therefore, it is appropriate to treat TR as a moderator variable.

The effect of TR is investigated here within the context of an attitude-adoption-response model.

Attitudes towards specific technological services have often formed a critical psychological antecedent of research into issues such as self-service, for instance see Lu et al. (2009), Bobbitt \& Dabholkar (2001) and Reinders, Dabholkar \& Frambach (2008).

Adoption of the self-service technology is obviously the overall aim of the designers, in this case the airlines and airports company jointly. Not only does adoption potentially save these organizations cost (Air Transport World \& SITA, 2016), but it hopefully facilitates a better and faster customer experience. Adoption of mobile check-in is therefore seen as important in this and similar models (Parasuraman, 2000; Tsikriktsis, 2004; Liljander et al., 2006; Walker \& Craig-Lees, 2002).

Response to mobile check-in is the ultimate end outcome, assessing the customer's post-use evaluations of relative satisfaction and perceptions of service quality. Level of response is seen as a critical antecedent of customer retention in general, but also of the customer's 
intention to continue using the self-service technology (Wang, Harris \& Patterson, in press; Dong, Sivakumar, Evans \& Zou, 2015).

This progression of attitudes to adoption and response is essentially based on the well-known Theory of Reasoned Action (Ajzen \& Fishbein, 1980), and underlies much consumer research.

In this paper, we focus on the moderating effect of TR on the direct relationships between attitudes and response to mobile check-in and adoption and response to mobile check-in respectively. Figure 1 shows these moderation relationships.

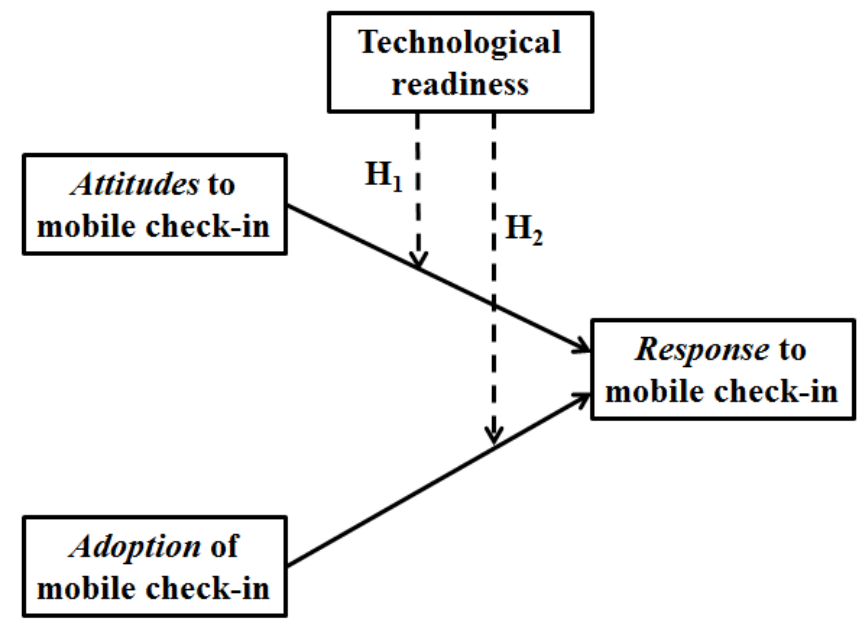

Figure 1: Technological readiness as a moderator of key relationships

The concomitant hypotheses are as follows:

$\mathrm{H}_{1}$ : Technological readiness (TR) moderates the relationship among attitudes towards the use of mobile check-in and response to mobile check-in, such that the relationship is significantly more positive with higher technological readiness.

$\mathrm{H}_{2}$ : Technological readiness (TR) moderates the relationship among attitudes towards the use of mobile check-in and response to mobile check-in, such that the relationship is significantly more positive with higher technological readiness.

The following sections discuss the empirical research testing this model.

\subsection{Research Design}

\section{Research Methodology}

The research is quantitative in approach, utilizing statistical analysis of a self-report survey as discussed further below. The survey was designed and administered by the Airports Company South Africa (ACSA), and the sample in this study includes those individuals who have experience of mobile check-in.

\subsection{The Research Instrument}

The research instrument is based strongly on that conducted by Liljander et al. (2006), including the following elements.

Attitude. Attitude towards mobile check-in is measured using 3 items from Currann \& Meuter (2005) on 1-7 point semantic differential scales with end points "Very Bad "(1) to "Very Good" (7) for attitudinal feelings, "Very Unpleasant "(1) to "Very Pleasant" (7) for attitudes towards use of mobile, and "Strongly Dislike "(1) to "Strongly Like" (7) for feelings of liking. A sample item: "When using mobile check-in, I generally feel:". The Cronbach alpha for the attitude set is .96. 
Adoption. Adoption of mobile check-in was measured using a single item from Curran et al. (2003) to measure respondents' frequency in use of, and intention to use, mobile check-in on a 1-7 point Likert scale from "Very Unlikely "(1) to "Very Likely" (7). The question is "I frequently use and intend making use of mobile check-in."

Responses. Response to mobile check-in is measured using a single item garnered from Lin \& Hsieh (2005) to measure respondents' overall satisfaction with the experience of using mobile check-in on a 1-7 point Likert scale from "Strongly Disagree "(1) to "Strongly Agree" (7). The item is worded: "Overall, I am satisfied and enjoy the quality of service when using mobile check-in".

Technology readiness. For this study $\mathrm{TR}$ is operationalized through the shortened Technology Readiness Index (Parasuraman, 2000), containing 12 TR related items on a 7 point Likert scale from "Strongly Disagree "(1) to "Strongly Agree" (7). The 12 items consist of four sub-dimensions of three items each, namely optimism toward technology, personal association with innovativeness, discomfort with technology, and insecurity with technology. A sample item from the optimism set is "Technology gives me more freedom of mobility".

Only innovativeness and optimism had adequate reliabilities of $\alpha=.84$ and $\alpha=.85$ respectively. The reliabilities of insecurity and discomfort were not acceptable with $\alpha=.53$ and $\alpha=.51$ respectively. However, when TR dimensions of insecurity and discomfort are grouped together and weaker elements removed, the resultant provides a stronger reliability score $\alpha=.66$.

Confirmatory factor analysis confirms this three-factor solution with good fit, with Chi-Square $=210.35(\mathrm{df}=51), \mathrm{SRMSR}=.05, \mathrm{RMSEA}=.066(90 \% \mathrm{CI}=.057-.076), \mathrm{CFI}=.94$, NNFI $=.92$. Since the sub-dimensions of TR may have differential moderation effects, they are kept separate in the analysis rather than forming a single TR factor.

Demographic data include gender, age, reason of travel, and class of ticket.

\subsection{Participants}

The population is the flying South African population using the services of commercial airlines operating in South Africa.

An online survey was developed by the Airports Company South Africa (ACSA) on the topic on self-service check-in technologies, and surveys distributed to airlines with a request to distribute the request to their lists of known passengers. 770 responses were received within a 3 week period. The response rate could not be calculated, as information relating to the list of airline databases was not shared and held confidential by respective airlines. Essentially, this constitutes a purposive sample.

None of the respondents were requested to provide names on the questionnaires, guaranteeing confidentiality.

Male respondents made up $76 \%$ of the sample. Travelling for business purposes was the main reason (69\%). $85 \%$ of respondents travelled economy class. A fairly representative sample was obtained with respect to ages (below 35 years old $=8.8 \%$, 35 years old to 44 years old $=$ $14 \%$, 45 years old to 54 years old $=26.9 \%$, 55 years old to 64 years old $=34.8 \%$, above 64 years old $=15.6 \%$ ). 


\section{Results}

Table 1 shows the salient correlations, means and standard deviations for the study.

Table 1: Correlations and descriptive statistics

\begin{tabular}{|c|c|c|c|c|c|c|c|c|c|}
\hline & $\mathbf{1}$ & 2 & 3 & 4 & 5 & 6 & 7 & 8 & 9 \\
\hline 1. Reason for Travel & 1.00 & & & & & & & & \\
\hline 2. Class of Ticket Purchased & $.09^{* * *}$ & 1.00 & & & & & & & \\
\hline 3. Male & $-.30^{* * * *}$ & $-.11^{* * *}$ & 1.00 & & & & & & \\
\hline 4. Age & $.07^{* *}$ & $.12^{* * * *}$ & $-.27^{* * *}$ & 1.00 & & & & & \\
\hline 5. TR (Innovativeness) & $.14^{* * * *}$ & .04 & $-.09^{* *}$ & $-.24^{* * *}$ & $(.84)$ & & & & \\
\hline 6. TR (Optimism) & $.09^{* * *}$ & -.03 & -.02 & $-.18^{* * * *}$ & $.67^{* * * *}$ & $(.85)$ & & & \\
\hline 7. TR (Negativity) & $-.09^{* * *}$ & .05 & .05 & $.10^{* * * *}$ & $-.42^{* * * *}$ & $-.55^{* * * *}$ & $(.66)$ & & \\
\hline 8. Adoption of Mobile & .06 & -.04 & -.05 & $-.17^{* * * *}$ & $.36^{* * *}$ & $.38^{* * *}$ & $-.26^{* * * *}$ & 1.00 & \\
\hline 9. Attitude towards Mobile & $.07^{*}$ & .00 & -.03 & $-.20^{* * * *}$ & $.43^{* * * *}$ & $.50^{* * * *}$ & $-.38^{* * * *}$ & $.77^{* * * *}$ & $(.96)$ \\
\hline 10. Mobile Response & .01 & -.05 & .00 & $-.20^{* * *}$ & $.33^{* * * *}$ & $.46^{* * * *}$ & $-.34^{* * * *}$ & $.74^{* * *}$ & $.81^{* * * *}$ \\
\hline $\mathbf{M}$ & 1.7 & 1.14 & 1.23 & $5 \cdot 32$ & 0.01 & -0.01 & 0.01 & 3.02 & 3.81 \\
\hline SD & 0.46 & 0.36 & 0.42 & 1.21 & 0.91 & 0.94 & 0.83 & 2.08 & 1.84 \\
\hline
\end{tabular}

Note: $N=761,{ }^{* * *}=p<.01,{ }^{* * *}=p<.05,{ }^{*}=p<.10$

As seen in Table 1, most of the expected main effect bivariate correlations are supported. Adoption of, attitude towards, and responses to mobile check-in are strongly correlated ( $\mathrm{r}>$ $.70, \mathrm{p}<.001)$. The three TR components have moderate associations with adoption, attitude and responses $(\mathrm{r}=.26-.51, \mathrm{p}<.01)$, and as can be expected these correlations are positive for sentiments of technological optimism and innovativeness and negative for technological negativity. Control variables mostly have small and negligible associations with key variables, except for a modest negative correlation between age and technological innovativeness ( $\mathrm{r}=$ $-.24, \mathrm{p}<.001)$.

Table 2 shows the key regression analyses, including the interaction terms for the moderations. As can be seen there, the interaction term is statistically significant for all three TR elements. Analysis of the standardized paths, however, which are not reported here due to space constraints, suggests that the interaction terms are only practically strong for optimism about technology $(B=.30, \mathrm{p}<.01$ for both attitude and adoption's paths on response to mobile check-in). 
Table 2: Moderation Of Technology Readiness On Attitude-Response And Adoption-Response Paths

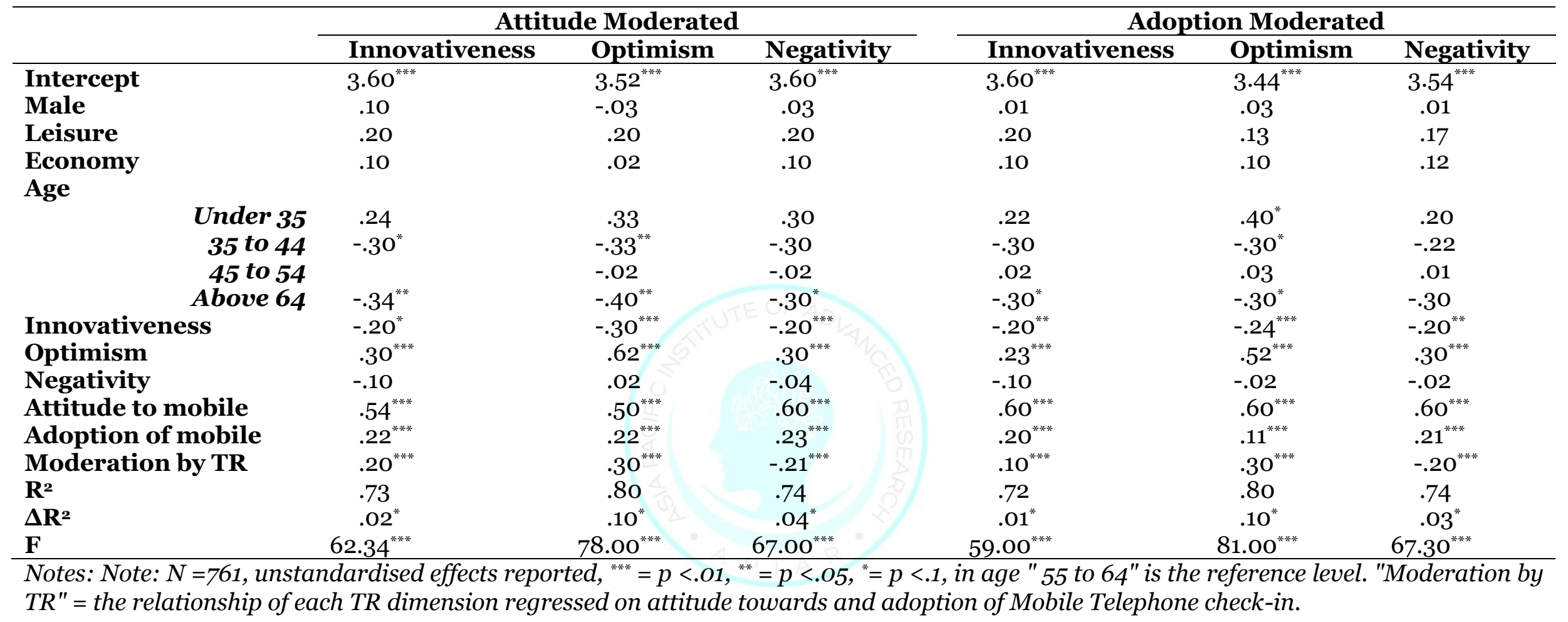


Accordingly, Figures 2 and 3 below show these effects.

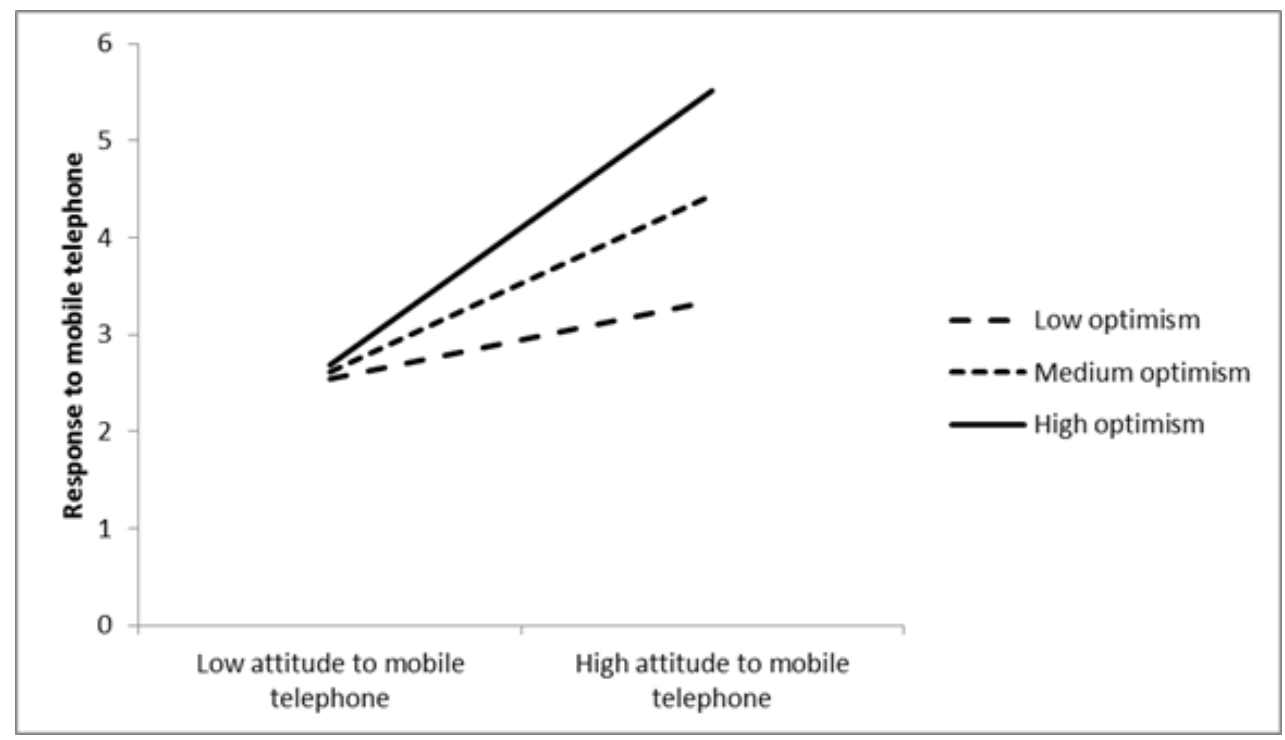

Figure 2: Technological optimism moderating the attitude-response path.

As can be seen in Figure 2, stronger technological optimism is associated with a stronger positive relationship between attitudes towards mobile and response to mobile use.

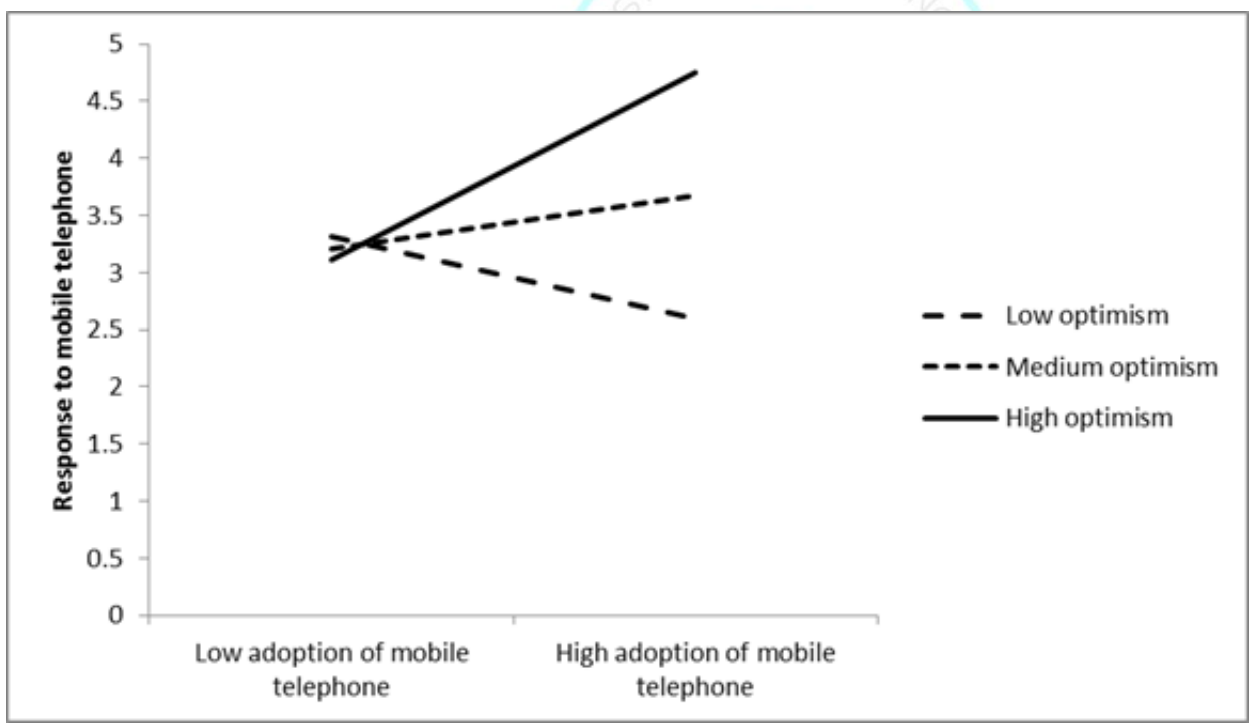

Figure 3: Technological optimism moderating the adoption-response path

As can be seen in Figure 3, higher technological optimism is associated with a more positive relationship between adoption of mobile and response to mobile, in fact low optimism suggests a negative main relationship here.

The demographic control variables in Table 2 show little effect on response, except for age for which older age groups have somewhat lower positive response to mobile.

\section{Discussion}

This research seeks to focus on a particularly specific question, namely whether elements of technological readiness act as moderators of reasoned action - type relationships. The below sections discuss these results. 


\section{Moderation of the Attitude-Response Relationship}

As expected, technological readiness - notably optimism about technology - moderates the relationship between mobile check-in attitudes and responses to mobile check-in. This provides partial support for $\mathrm{H}_{1}$.

The moderation here suggests that more positive attitudes towards mobile check-in lead to more positive responses, but that this is stronger under conditions of higher technological readiness. Readiness seems to act as an enhancing factor, that potentially adds self-efficacy to the more general positive affective state (Dabholkar \& Bagozzi, 2002).

\section{Moderation of the Adoption-Response Relationship}

As expected, technological readiness - notably optimism about technology - moderates the relationship between mobile check-in attitudes and responses to mobile check-in. This provides partial support for $\mathrm{H}_{2}$.

These results are similar to those found by Dong et al. (2015), who modelled 'participation readiness' as a moderator of the customer participation - service outcomes relationship. Similar to our findings, they conclude that involving customers can be positive under conditions of high readiness, but that low readiness can even lead to a negative relationship. In both these research streams, customer stress due to involvement without requisite readiness may be the underlying cause of the negative relationship (Meuter, Ostrom, Bitner \& Roundtree, 2003).

\section{Practical Implications}

These findings are of psychological interest, but perhaps present challenges with regard to practical implications. One possibility may be to offer consumers various levels of complexity in the mobile application launch pages, with at least a streamlined and full-feature options being offered.

Allowing more or less technologically adept consumers a choice may facilitate better attitudes and responses.

In addition, airlines may help passengers become more technologically ready, perhaps by educational initiatives. One option may be to include videos on alternative check-in options in the in-flight entertainment packages, which may be especially salient to passengers fresh from difficult check-in experiences and attract more of such passengers to options such as mobile.

\section{Limitations}

This research has several limitations which may suggest avenues for improvements in further research.

The sample is, of course, limited to South African fliers and; therefore, may lack generalizability to some extent. Further research in the rest of the African continent would be exceptionally valuable given the growth potential there. It is also not a random sample, having been gathered through convenience methods and blind database mails.

The measures were chosen by ACSA for purposes of a streamlined survey, and therefore are single-item measures in many cases rather than multi-item scales. This may affect reliability, and the seven-item scales may have limited variability. Future research could improve on these measures, and add more control variables given the lack of impact seen here on all controls except for age. 
It is clear from normal 'reasoned action' research that inclusion of a mediating path would be appropriate, i.e. where adoption mediates between attitudes and responses. This study focused on the moderation and therefore did not include this possibility.

\section{Conclusion}

This paper has seemingly shown that technological readiness may be a significant factor in the success of mobile technologies in the internet-dominated space of airline check-in. Given that mobile applications make sense in the South African and similar contexts (where mobile connectivity has far outstripped internet access for the population), understanding facilitators or inhibitors such as technological readiness may help to advance use of such options. In addition, since airlines and airports have discovered cost savings and other advantages in passenger self-service, this paper may add a small, but significant element to their efforts to expand check-in options. 


\section{References}

i. $\quad$ Air Transport World and SITA, 2016. 2016 Air Transport Industry Insights: The Passenger IT Trends Survey. URL:

https://www.sita.aero/resources/type/surveys-reports/passenger-it-trends-survey-2016

ii. Airports Company South Africa website, 2017. URL:

http://www.airports.co.za/about-us/airports-company/milestone-in-our-history

iii. Ajzen, I. \& Fishbein, I., 1980. Understanding Attitudes and Predicting Social Behavior (1 ${ }^{\text {st }}$ ed), NJ: Prentice Hall.

iv. Bobbitt, L. M. \& Dabholkar, P. A., 2001. Integrating Attitudinal Theories to Understand and Predict use of Technology-Based Self Service. International Journal of Service Industry Management, 12(5), pp. 423-450.

v. Curran, J. M., Meuter, M. L. \& Surprenant, C. F., 2003. Intentions to use Self-Service Technologies: A Confluence of Multiple Attitudes. Journal of Service Research, 5(3), pp. 209-224.

vi. Currann M. J. \& Meuter, M. L., 2005. Self-Service Technology Adoption: Comparing Three Technologies, Journal of Services Marketing. 19(2), pp. 103-113.

vii. Dabholkar, P. A., 1996. Consumer Evaluations of New Technology-Based Self Service Options: An Investigation of Alternative Models Of Service Quality. International Journal of Research in Marketing, 13(1), pp. 29-51.

viii. Dabholkar, P. A., 2000. Technology in Service Delivery: Implications for Self-Service and Support, Beverly Hills, CA: Sage Publications.

ix. $\quad$ Dabholkar, P. A. \& Bagozzi, R. P., 2002. An Attitudinal Model of Technology-Based Self-Service: Moderating Effects of Consumer Traits and Situational Factors. Journal of the Academy of Marketing Science, 30(3), pp. 184-201.

x. $\quad$ Dong, B., Sivakumar, K., Evans, K. R. \& Zou, S., 2015. Effect of Customer Participation on Service Outcomes: The Moderating Role of Participation Readiness. Journal of Service Research, 18(2), pp. 160-176.

xi. Liljander, V., Gillberg, F., Gummerus, J. \& van Riel, A., 2006. Technology Readiness and the Evaluation and Adoption of Self-Service Technologies. Journal of Retailing and Consumer Services, 13, pp. 177-191.

xii. $\quad$ Lin J. S. C. \& Hsieh, P. L., 2006. The Role of Technology Readiness in Customers' Perception and Adoption of Self-Service Technologies. International Journal of Service Industry Management, 17(5), pp. 497-517.

xiii. Lin, J. S. C \& Chang, H. C., 2011. The Role of Technology Readiness in Self-Service Technology Acceptance. Managing Service Quality: An International Journal, 21(4), pp. 424-444.

xiv. Lin, J. S. C. \& Hsieh, P. L., 2005. The Influence of Technology Readiness on Satisfaction and Behavioural Intentions toward Self-Service Technologies. Computers in Human Behaviour, 23 , pp. 1597-1615.

xv. Lu, J. L., Chou, H. Y. \& Ling, P. C., 2009. Investigating Passengers' Intentions to use Technology-Based Self Check-In Services. Transportation Research Part E: Logistics and Transportation Review, 45(2), pp. 345-356.

xvi. $\quad$ Meuter, M. L., Ostrom, A. L., Bitner, M. J. \& Roundtree, M. J., 2003. The Influence of Technology Anxiety on Consumer Use and Experiences with Self-Service Technologies. Journal of Business Research, 56(11), pp. 899-906.

xvii. Mick, D. G. \& Fournier, S., 1998. Paradoxes of Technology: Consumer Cognizance, Emotions and Coping Strategies. Journal of Consumer Research, 25(2), pp. 123-144.

xviii. Parasuraman, A., 2000. Technology Readiness Index: A Multiple-Item Scale to Measure Readiness to Embrace New Technologies. Journal of Service Research, 2(4), pp. 307-321. 
xix. Pew Research Center. 2015. Report on African Mobile Connectivity and Use. URL: http://www.pewglobal.org/2015/04/15/cell-phones-in-africa-communication-lifeline/

xx. $\quad$ Reinders, M.J., Dabholkar, P. A. \& Frambach, R. T., 2008. Consequences of Forcing Consumers to Use Technology-Based Self-Service. Journal of Service Research, 11(2), pp. 107-123.

xxi. Taylor, S. A., Celuch, K. \& Goodwin, S., 2002. Technology Readiness in the E-Insurance Industry: An Exploratory Investigation and Development of an Agent Technology E-Consumption Model. Journal of Insurance Issues, 25(2), pp. 142-166.

xxii. Tsikriktsis, N., 2004. A Technology Readiness-Based Taxonomy of Customers. Journal of Service Research, 7(1), pp. 42-52.

xxiii. Walker, R. \& Craig-Lees, M., 2002. Technology Enabled Service Delivery. International Journal of Service Industry Management, 13 (1), pp. 91-106.

xxiv. Wang, C., Harris, J. \& Patterson, P. G., in press. Modeling the Habit of Self-Service Technology Usage. Australian Journal of Management, in press.

xxv. Zeithaml, V. A., Parasuraman, A. \& Malhotra, A., 2002. Service Quality through Web Sites. Journal of the Academy of Marketing Science, 13(4), pp. 362-376. 